\title{
Population Densities of Tylenchulus semipenetrans Related to Physicochemical Properties of Soil and Yield of Clementine Mandarin in Spain
}

Francisco Javier Sorribas, Departament d'Enginyeria Agroalimentària i Biotecnologia, Universitat Politècnica de Catalunya, Campus Baix Llobregat, Edifici ESAB, Av. Canal Olímpic s/n, 08860 Barcelona, Spain; Soledad Verdejo-Lucas, IRTA, Protecció Vegetal, Crta. De Cabrils km2, 08348, Cabrils, Barcelona, Spain; Joaquín Pastor, IRTA, Estació Experimental de l'Ebre, Apartat de Correus 203, 43870 Amposta, Tarragona, Spain; Cesar Ornat, Departament d'Enginyeria Agroalimentària i Biotecnologia, Universitat Politècnica de Catalunya, Barcelona, Spain; Joan Pons, IRTA, Estació Experimental de l'Ebre, Tarragona, Spain; and Jordi Valero, Departament de Matemàtica Aplicada III, Universitat Politècnica de Catalunya, Barcelona, Spain

\begin{abstract}
Sorribas, F. J., Verdejo-Lucas, S., Pastor, J., Ornat, C., Pons, J., and Valero, J. 2008. Population densities of Tylenchulus semipenetrans related to physicochemical properties of soil and yield of clementine mandarin in Spain. Plant Dis. 92:445-450.

A survey was conducted from April to June 2002 in 62 orchards of clementine mandarin grafted on Troyer or Carrizo citrange rootstock in Catalonia (northeastern Spain) to determine the relationship between physicochemical soil properties and Tylenchulus semipenetrans population densities. Soil was analyzed to determine texture, $\mathrm{pH}$, electric conductivity, organic matter content, N, P, K, Mg, calcium carbonate, and calcium oxide. Also, trials were conducted in 2003 and 2004 in three drip-irrigated orchards of clementine mandarin cv. Clemenules (El Pla and Mariclaire) or cv. Hernandina (Martorella) to determine the relationship between citrus nematode densities and yield of mandarin. T. semipenetrans was detected in $77 \%$ of the surveyed orchards. The number of second-stage juveniles + males in soil was related to $\mathrm{N}$ and $\mathrm{K}$ soil content $\left(3.57953-0.001305 \mathrm{~N}+0.00113 \mathrm{~K}, R^{2}=0.1620, P<0.0157\right)$. The relationship between relative yield of clementine mandarin cv. Clemenules and densities of females per gram of root in spring was described by the Seinhorst damage function model $\left(0.035+0.965(0.9995)^{(\mathrm{Pi}-287)}, R^{2}\right.$ $=0.4782, P<0.0001)$.
\end{abstract}

Additional keywords: gain threshold, plant-parasitic nematodes

Spain is the largest citrus producer of Europe, with an annual production that exceeds 5 million metric tons per year. Citrus crops are cultivated on about 280,000 ha in coastal areas and river valleys in eastern and southern Spain. Citrus is important socioeconomically because it provides a large source of foreign currency and because, due to the generally small orchard size and labor-intensive nature of the crop, it generates employment for many families.

The citrus nematode, Tylenchulus semipenetrans Cobb, is the most important plant-parasitic nematode of citrus worldwide. Mature trees can tolerate large numbers of these nematodes before exhibiting lack of vigor or decline symptoms; however, young trees grow poorly if replanted into nematode-infested soils (9). The identification of factors that regulate popula-

Corresponding author: F. J. Sorribas

E-mail: francesc.xavier.sorribas@upc.edu

Accepted for publication 23 October 2007.

doi:10.1094/PDIS-92-3-0445

(C) 2008 The American Phytopathological Society tion densities is needed to estimate the potential of the nematode to damage citrus and to cause yield losses. Although $T$. semipenetrans develops in any soil suitable for citrus growth, some physicochemical properties of soil can favor or inhibit nematode population development in a direct or indirect manner. Thus, moderate amounts of clay and silt favor population development $(1,4,25,39)$. The amount of organic matter in soil can favor (27), have no effect $(1,25)$, or inhibit the increase of nematode population densities (25). The $\mathrm{pH}$ has a positive relationship with nematode population densities in soil $(1,4,19)$. In saline soils, nematode population on salt-stressed plants increase when salinity decreases during the rainy season (22). Magnesium content in the soil was directly related to fungal parasitism of nematode eggs which, in turn, will affect population densities of T. semipenetrans (13).

Damage thresholds, the minimum nematode population densities that reduce tree growth and yield, are influenced by nematode reproduction rate, susceptibility of the rootstock, climatic conditions, soil properties, presence of other pathogens or microbial antagonists, and orchard management practices $(7,9)$. Therefore, the estimate of damage thresholds must be based on the factors that affect the nematode in a given region. For example, nematicide treatments are recommended when the populations exceeds 400 females per gram of root in February to April or 700 in May to June in California (12), 100 females per gram of root in South Africa (17), or 20 juveniles $/ \mathrm{cm}^{3}$ of soil in Cyprus (29). Most studies estimate yield losses due to $T$. semipenetrans to be in the range of 0 to $30 \%$ depending on the infestation level and orchard management $(2,3,6,10,14,36,37)$.

In Spain, T. semipenetrans is present in more than $80 \%$ of the established orchards in the regions of Valencia and Andalucía $(1,25,26)$ but its distribution in the Catalonian region (northeastern Spain) was unknown. This region is the northernmost territory of the country to grow citrus because of restrictions imposed by climatic conditions. In Catalonia, orchards of clementine mandarin (Citrus clementina Hort. ex Tan.) represent $77 \%$ of the hectarage in the region, of which $52 \%$ is cultivated with cv. Clemenules. Moreover, information on yield losses caused by $T$. semipenetrans under the conditions prevailing in Spain is unreported. Therefore, the objectives of this study were to (i) determine population densities of $T$. semipenetrans in clementine mandarin citrus orchards in Catalonia (northeastern Spain), (ii) determine their relationship to physicochemical properties of the soil, and (iii) determine the relationship between citrus nematode densities and clementine mandarin yield.

\section{MATERIALS AND METHODS}

Nematode survey. Composite soil and root samples were collected from 62 orchards of clementine mandarin grafted on Troyer or Carrizo citrange rootstocks. Orchards were located in four geographical areas of the Baix Ebre and Montsià counties in Catalonia, Spain, and they were representative of orchards located near the coast ( 25 orchards), inland (15 orchards), riverside (11 orchards), and new citrusgrowing areas previously cultivated with olive or almonds (11 orchards). The age of the orchards ranged from 6 to 26 years. All 
orchards were drip irrigated. The orchards were sampled from April to June 2002. From each orchard, about $3 \mathrm{~kg}$ of soil and roots were collected with a spade from the top $25 \mathrm{~cm}$ of soil from the area wetted by irrigation drippers surrounding eight arbitrarily selected trees, one sample per tree. Soil and roots were combined and mixed, and a sample of about $2 \mathrm{~kg}$ was bagged, labeled, and taken to the laboratory for nematode analysis. The remaining $1 \mathrm{~kg}$ was used to determine physicochemical properties of soil. Nematode population densities in both soil and roots were assayed for each orchard. Samples were sieved through a 4-mm aperture screen to remove stones and separate roots from soil. Nematodes were extracted from a $500-\mathrm{cm}^{3}$ soil subsample on Baermann trays that had a screen surface area of $280 \mathrm{~cm}^{2}$. Secondstage juveniles (J2) and males that migrated to the water were collected 1 week later, concentrated on a $25-\mu \mathrm{m}$-pore sieve, counted, and expressed as $\mathrm{J} 2+$ males per $250 \mathrm{~cm}^{3}$ of soil. Nematodes and eggs were extracted from roots that were carefully washed free of soil and chopped. A 5-g subsample was placed in a food blender jar (Hamilton Beach 1G58200, WA) containing a $0.05 \% \mathrm{NaOCl}$ solution. The roots were macerated at maximum speed for two successive 15-s intervals (24). The suspension of nematodes and eggs then was sieved through a $74-\mu \mathrm{m}$ screen to remove root debris and concentrated on a $20-\mu \mathrm{m}$ screen to collect nematode eggs. The numbers of females and eggs were counted and expressed per gram of fresh root tissue. Other plant-parasitic nematodes from soil and roots samples also were counted.

Physicochemical properties. A $1-\mathrm{kg}$ soil sample from the $3 \mathrm{~kg}$ taken from each orchard in the nematode survey study was sent to the Laboratory of Analyses and Soil Fertility, Sidamon, Lleida, Spain to deter- mine soil texture (United States Department of Agriculture classification), soil $\mathrm{pH}$ in water (1:2.5, soil:water), electrical conductivity $(\mathrm{dS} / \mathrm{m})$, organic matter $(\%)$, and content of $\mathrm{N}$ ( $\mu \mathrm{g} /$ liter), $\mathrm{P}$ ( $\mu \mathrm{g} /$ liter), $\mathrm{K}$ ( $\mu \mathrm{g} / \mathrm{liter}), \mathrm{Mg}(\mu \mathrm{g} / \mathrm{liter})$, calcium carbonate $(\%)$, and calcium oxide $(\%)$.

Yield trial. The study was carried out in three drip-irrigated clementine mandarin orchards: cv. Hernandina was planted at the Martorella orchard in Alcanar, Tarragona; and cv. Clemenules was planted at the El Pla orchard in Alcanar, Tarragona and at the Mariclaire orchard in Traiguera, Castellón (Table 1). The orchards were located in the same area near the coast and were selected from the survey study because they had high infestation levels of the citrus nematode. At each orchard, 10 plots consisting of six trees each were marked in arbitrarily selected rows. These trees were of similar size and trees that appeared unhealthy or undersized were avoided (5). Composite soil and root samples were collected from three trees per plot as described for the nematode survey to determine nematode levels before the beginning of the trials. The orchards were sampled thereafter in March and October (El Pla and Martorella) or only in March (Mariclaire) for two consecutive years, 2003 and 2004. At each sampling time, one composite soil and root sample from three trees per plot, one subsample per tree, were collected from the top $25-\mathrm{cm}$ soil layer with a spade as previously described. Nematodes in soil and roots were extracted as indicated in the survey.

To assess yield, mature fruit were collected and weighed in a single picking. Yield was expressed as kilograms per tree. The economic threshold, defined as the nematode population density at which the value of the damage caused is equal to the cost of control (11), was calculated for

Table 1. Main characteristics, history, and physicochemical properties of the soils of the three orchards of clementine mandarin selected for the yield trial

\begin{tabular}{llll}
\hline & \multicolumn{3}{c}{ Orchard } \\
\cline { 2 - 4 } Characteristics & Martorella & El Pla & Mariclaire \\
\hline Cultivar & Hernandina & Clemenules & Clemenules \\
Rootstock & Carrizo Citrange & Carrizo Citrange & Troyer Citrange \\
Previous crop & Citrus & Citrus & Citrus nursery \\
Replanted & 1994 & 1996 & 1989 \\
Trees per hectare & 519 & 500 & 800 \\
Soil pH $(1: 2.5$ water) & 8.1 & 8.2 & 8.1 \\
Electric conductivity $(\mathrm{dS} / \mathrm{m})$ & 0.35 & 0.32 & 0.25 \\
Organic matter $(\%)$ & 4.2 & 4.5 & 3.3 \\
Calcium carbonate $(\%)$ & 18 & 33 & 39 \\
Calcium oxide $(\%)$ & 4 & 3 & 5 \\
Nitrogen $(\mu \mathrm{g} /$ /iter) & 31 & 20 & 17 \\
Phosphorus $(\mu \mathrm{g} /$ liter $)(\mathrm{Olsen})$ & 170 & 199 & 117 \\
Potassium $(\mu \mathrm{g} / \mathrm{liter})$ & 404 & 526 & 282 \\
Magnesium $(\mu \mathrm{g} / \mathrm{liter})$ & 573 & 544 & 416 \\
Sand $(\%)$ & 43.2 & 49.4 & 53.2 \\
Fine silt $(\%)$ & 13.0 & 13.6 & 14.8 \\
Coarse silt $(\%)$ & 23.4 & 14.9 & 16.1 \\
Clay $(\%)$ & 20.4 & 22.2 & 15.9 \\
Soil texture $(\mathrm{USDA})^{\mathrm{z}}$ & Loam & Loam & Sandy loam \\
\hline
\end{tabular}

${ }^{\mathrm{z}}$ United States Department of Agriculture. each mandarin cultivar and year considering the gain threshold, the value of harvested mandarin that equals the cost of control (30), and the relationship between nematode densities and yield. The cost of controlling the nematode by any of the nematicides presently registered in Spain for citrus (ethoprophos, oxamyl, carbofuran, and sodium tetrathiocarbonate) ranges from 0.38 to 2.5 euros per tree, considering 500 trees/ha. We considered the lower and upper treatment cost of those nematicides for calculation. The average price to growers of $1 \mathrm{~kg}$ of mandarins was 0.25 euros in 2003 and 0.17 euros in 2004.

Statistical analyses. All statistical analysis were done using the SAS system V8 (SAS Institute Inc., Cary, NC). A cluster analysis (proc cluster) was used to group orchards according to soil physicochemical properties by the maximum likelihood clustering method. Orchards grouped by the cluster analysis were submitted to a canonical discriminant analysis using the candisc procedure (proc candisc) to elucidate the main factors that determine the differences between the groups. Data from the survey orchards were subjected to correlation analysis (proc corr) to determine the relationship between each physicochemical property of the soil and population densities of females per $\mathrm{g}$ of root or $\mathrm{J} 2+$ males of $T$. semipenetrans $/ 250 \mathrm{~cm}^{3}$ of soil. Also, multiple regression analysis was performed to determine those combinations of variables that explained variability in nematode population densities. Only data from orchards infested with the citrus nematode were used for the regression analyses. Nematode counts were transformed to $\log _{10}(x+1)$ and subjected to analyses using the regression procedure (proc reg) with the backward model selection at a significance level of $P=0.05$.

Densities of females and eggs per gram of root and $\mathrm{J} 2+$ males $/ 250 \mathrm{~cm}^{3}$ of soil from the yield trials were compared between sampling times and years in each orchard. Nematode counts were transformed to $\log _{10}(x+1)$ and means subjected to Student's $t$ tests. Regression analysis was used to determine the relationship between mandarin yield and densities of females in roots or $\mathrm{J} 2+$ males in soil in spring. Cultivars were analyzed separately because the alternate bearing behavior of cv. Hernandina $(20,21)$. The relative yield for the same regressor, females or $\mathrm{J} 2+$ males, was calculated by dividing actual yield by their intercept from the linear regression analysis. A new regression analysis then was performed by cultivar to determine the goodness of fit using nonlinear regression (proc nlin).

\section{RESULTS}

Nematode survey. Eight genera of plant-parasitic nematodes were present in 57 of 62 mandarin orchards surveyed in Catalonia. T. semipenetrans was detected 
in 48 of the 62 surveyed orchards, which represented a frequency of occurrence of $77 \%$. An orchard was considered infested if citrus nematode females were recovered from the roots.

The genus Paratylenchus was found in 24 of the orchards (39\%), with population densities that ranged from 21 to 555 nematodes $/ 250 \mathrm{~cm}^{3}$ of soil $(167 \pm 177$, mean \pm standard deviation). The nematode was recovered mainly from soil samples but also from citrus roots (five orchards). Other plant-parasitic nematodes found, although in low numbers, in the soil included Helicotylenchus spp. in $10 \%$ of the orchards, Tylenchorhynchus spp. in $6 \%$ of the orchards, and a criconematid in $5 \%$ of the orchards. Zygotylenchus guevarai (Tobar Jiménez) Braun and Loof, Tetylenchus spp., and Longidorus spp. were found in only $1.6 \%$ of the orchards.

Physicochemical properties. The cluster analysis grouped the orchards in seven clusters according to the physicochemical properties of the soil. Cluster 1 included 13 orchards located inland (7 orchards) and near the coast ( 6 orchards); cluster 2 included 7 orchards located near the coast (5 orchards) and in riverside areas (2 orchards); cluster 3 included 12 orchards located inland (5 orchards), near the coast (5 orchards), in riverside areas ( 1 orchard), and in new citrus-growing areas (1 orchard); cluster 4 included 13 orchards located in new citrus-growing areas (5 orchards), near the coast (4 orchards), inland ( 2 orchards), and in riverside areas (2 orchards); cluster 5 included 13 orchards located in riverside (6 orchards) and new citrus-growing areas (5 orchards), inland ( 1 orchard), and near the coast (1 orchard); cluster 6 included 3 orchards located near the coast; and cluster 7 included only 1 orchard, also located near the coast. The clusters differed for potassium, magnesium, organic matter, and clay content of soil (Table 2). The physical and chemical variables were distributed in two dimensions (Fig. 1) that explained $97 \%$ of the total variance, 84.5 and $12.4 \%$ for the first and second dimension, respectively. A wide range of population densities occurred in the orchards (Table 3), but they did not differ (females per gram of root, $P$ $=0.38$; eggs per gram of root, $P=0.49 ; \mathrm{J} 2$ + males $/ 250 \mathrm{~cm}^{3}$ of soil, $P=0.50$ ) among orchards grouped by common edaphic characteristics. No correlation was found between single physicochemical variables and population densities of females in roots or $\mathbf{J} 2+$ males in soil. However, multiple regression analysis showed that the number of $\mathrm{J} 2+$ males in soil was related to $\mathrm{N}$ and $\mathrm{K}$ soil content $(3.57953-0.001305$ $\left.\mathrm{N}+0.00113 \mathrm{~K}, R^{2}=0.1620, P<0.0157\right)$.

Yield trials. Average infestation levels at the start of the trials (spring 2003 samples) were greatest at El Pla and least at Martorella (Table 4). Citrus nematode population densities differed between sampling times within and between years. In general, they were higher $(P<0.05)$ in spring than autumn and in 2003 than 2004 (Table 4). Females and eggs per gram of root and $\mathrm{J} 2+$ males in soil at Martorella in spring were higher $(P=0.0002,0.0063$, and 0.0197 , respectively) in 2003 than 2004. In autumn, females per gram of root and $\mathrm{J} 2+$ males in soil were higher $(P=$ 0.0044 and 0.0309 , respectively) in 2003 than 2004. At El Pla, females and eggs per gram of root and $\mathbf{J} 2+$ males in soil were higher $(P<0.0001,0.0001$, and 0.0001, respectively) in spring 2003 than 2004. In autumn 2004, females per gram of root and $\mathrm{J} 2+$ males in soil were lower $(P=0.0073$ and 0.0031, respectively) than 2003. At Mariclaire, densities of $\mathrm{J} 2+$ males in soil were higher $(P=0.0023)$ in spring 2003 than 2004 (Table 4).

Regression between nematode population densities and mandarin yield was performed, combining data over years and locations according to clementine cultivars. Yield of cv. Clemenules was related to densities of females per gram of root in spring (79.28 to 0.02712 females per gram of root; $R^{2}=0.469 ; P=0.0001$ ) but unre- lated to $\mathrm{J} 2$ + males in soil. In contrast, yield of cv. Hernandina was not related to either females per gram of root or $\mathrm{J} 2+$ males in soil, probably due to the alternate behavior of this cultivar. The Seinhorst damage function model described the relationship between relative yield of clementine mandarin cv. Clemenules and densities of females/g root in spring $\left(R^{2}=\right.$ $0.4782 ; P<0.0001 ;$ Fig. 2$)$. The tolerance limit, defined as the minimal density below which no measurable yield loss occurs (33), was $287 \pm 183$ (mean $\pm 95 \%$ confidence limits) females per gram of root (Fig. 2). The gain threshold, the value of harvested mandarin that equals the cost of control with ethoprophos, was $1.53 \mathrm{~kg} /$ tree in 2003 and $2.24 \mathrm{~kg} /$ tree in 2004. For sodium tetrathiocarbonate, the gain threshold was $10.03 \mathrm{~kg} /$ tree in 2003 and 14.76 $\mathrm{kg} /$ tree in 2004. The estimated economic thresholds for ethoprophos was 330 females per gram of root in 2003 and 350 females per gram of root in 2004. Economic threshold for sodium tetrathiocarbonate was 570 females per gram of root in 2003 and 710 females per gram of root in 2004.

Table 2. Statistical significance (in bold) of the physicochemical properties of the soil that explained differences among the 62 orchards of clementine mandarin sampled in Catalonia, northeastern Spain

\begin{tabular}{|c|c|c|c|c|}
\hline Variable & $R^{2}$ & $R^{2} /\left(1-R^{2}\right)$ & $F$ value & $P r>F$ \\
\hline $\mathrm{pH}$ & 0.0696 & 0.0749 & 0.67 & 0.6713 \\
\hline Electric conductivity & 0.1348 & 0.1558 & 1.40 & 0.2306 \\
\hline Organic matter $(\%)$ & 0.3530 & 0.5456 & 4.91 & 0.0005 \\
\hline $\mathrm{N}(\mu \mathrm{g} / \mathrm{liter})$ & 0.1091 & 0.1225 & 1.10 & 0.3730 \\
\hline $\mathrm{P}(\mu \mathrm{g} / \mathrm{liter})$ & 0.1481 & 0.1739 & 1.56 & 0.1753 \\
\hline $\mathbf{K}(\boldsymbol{\mu g} /$ liter $)$ & 0.8717 & 6.7961 & 61.17 & $<0.0001$ \\
\hline Calcium carbonate $(\%)$ & 0.1352 & 0.1564 & 1.41 & 0.2289 \\
\hline Calcium oxide $(\%)$ & 0.1591 & 0.1893 & 1.70 & 0.1380 \\
\hline Mg ( $\mu \mathrm{g} /$ liter $)$ & 0.8240 & 4.6802 & 42.12 & $<0.0001$ \\
\hline Sand $(\%)$ & 0.0907 & 0.0998 & 0.90 & 0.5033 \\
\hline Fine silt (\%) & 0.0654 & 0.0699 & 0.63 & 0.7059 \\
\hline Coarse silt (\%) & 0.0734 & 0.0792 & 0.71 & 0.6410 \\
\hline Clay $(\%)$ & 0.2629 & 0.3566 & 3.21 & 0.0091 \\
\hline
\end{tabular}

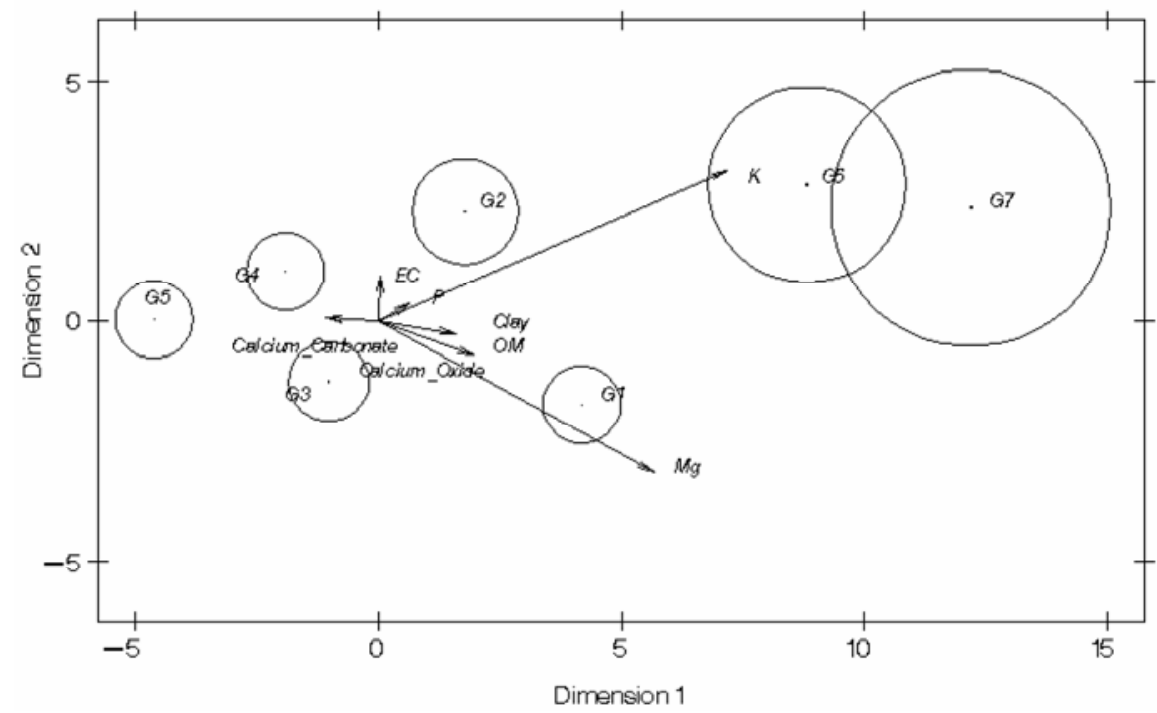

Fig. 1. Canonical discriminant analysis of seven cluster groups grouped by physicochemical properties of soil of 62 orchards of clementine mandarin from Catalonia (northeastern Spain). G1 to G7 indicate cluster groups. 
Table 3. Number of Tylenchulus semipenetrans females and eggs per gram of root and second-stage juveniles (J2) + males $/ 250 \mathrm{~cm}^{3}$ of soil in clementine mandarin orchards located in four geographical areas of Catalonia (northeastern Spain)

\begin{tabular}{|c|c|c|c|c|}
\hline $\begin{array}{l}\text { Area, } \\
\text { orchard number }\end{array}$ & Females & Eggs & $\mathrm{J} 2+$ males & $\begin{array}{c}\text { Other plant-parasitic } \\
\text { nematodes }\end{array}$ \\
\hline \multicolumn{5}{|l|}{ Riverside } \\
\hline 1.1 & 160 & 12,608 & 4,674 & $\ldots$ \\
\hline 1.2 & 600 & 21,440 & 11,883 & $\ldots$ \\
\hline 1.4 & 8 & 216 & 651 & Paratylenchus, criconematid \\
\hline 1.6 & 52 & 2,184 & 3,186 & Paratylenchus \\
\hline 1.7 & 20 & 857 & 1,925 & Paratylenchus \\
\hline 1.8 & 1,027 & 16,472 & 4,633 & Paratylenchus \\
\hline 1.9 & 189 & 6,742 & 6,050 & Paratylenchus \\
\hline 1.10 & 1,920 & 17,040 & 10,416 & Paratylenchus \\
\hline 1.11 & 5 & 738 & 630 & $\ldots$ \\
\hline \multicolumn{5}{|l|}{ New citrus area } \\
\hline 2.1 & 18 & 936 & 259 & Paratylenchus, criconematid \\
\hline 2.2 & 450 & 10,604 & 2,242 & criconematid \\
\hline 2.3 & 1,152 & 12,700 & 23,147 & $\ldots$ \\
\hline 2.5 & 842 & 23,057 & 13,579 & $\ldots$ \\
\hline 2.6 & 1,120 & 19,360 & 16,320 & $\ldots$ \\
\hline 2.7 & 1,225 & 10,942 & 13,293 & $\ldots$ \\
\hline 2.8 & 12 & 12 & 138 & $\ldots$ \\
\hline 2.9 & 12 & 81 & 148 & $\ldots$ \\
\hline 2.10 & 1,437 & 17,900 & 61,200 & $\ldots$ \\
\hline 2.11 & 1,440 & 33,720 & 58,266 & $\ldots$ \\
\hline \multicolumn{5}{|l|}{ Inland } \\
\hline 3.2 & 67 & 2,554 & 2,128 & Paratylenchus \\
\hline 3.4 & 764 & 9,130 & 12,390 & $\ldots$ \\
\hline 3.5 & 672 & 11,104 & 11,200 & $\ldots$ \\
\hline 3.6 & 131 & 1,148 & 1,696 & $\ldots$ \\
\hline 3.7 & 58 & 818 & 3,993 & $\ldots$ \\
\hline 3.8 & 720 & 31,500 & 5,900 & $\ldots$ \\
\hline 3.9 & 39 & 437 & 1,316 & $\ldots$ \\
\hline 3.11 & 554 & 11,981 & 12,500 & $\ldots$ \\
\hline 3.12 & 954 & 33,326 & 10,199 & $\ldots$ \\
\hline 3.14 & 55 & 82 & 155 & $\ldots$ \\
\hline \multicolumn{5}{|l|}{ Near the coast } \\
\hline 4.1 & 648 & 9,493 & 29,941 & $\ldots$ \\
\hline 4.2 & 422 & 4,805 & 9,638 & $\ldots$ \\
\hline 4.3 & 400 & 9,640 & 6,740 & $\ldots$ \\
\hline 4.4 & 80 & 1,960 & 2,280 & Paratylenchus \\
\hline 4.5 & 1,080 & 56,880 & 15,555 & $\ldots$ \\
\hline 4.7 & 110 & 2,355 & 4,015 & Paratylenchus, Helicotylenchus \\
\hline 4.8 & 640 & 13,960 & 11,036 & $\ldots$ \\
\hline 4.10 & 240 & 1,350 & 740 & Paratylenchus \\
\hline 4.11 & 111 & 5,562 & 9,856 & $\ldots$ \\
\hline 4.13 & 199 & 9,030 & 7,744 & $\ldots$ \\
\hline 4.15 & 64 & 1,392 & 9,664 & $\ldots$ \\
\hline 4.16 & 360 & 16,620 & 21,480 & $\ldots$ \\
\hline 4.18 & 275 & 9,460 & 39,678 & $\ldots$ \\
\hline 4.19 & 221 & 9,448 & 18,526 & Paratylenchus \\
\hline 4.20 & 224 & 5,024 & 18,120 & $\ldots$ \\
\hline 4.21 & 465 & 11,753 & 52,000 & $\ldots$ \\
\hline 4.22 & 2,280 & 63,960 & 22,500 & $\ldots$ \\
\hline 4.23 & 672 & 12,608 & 19,690 & $\ldots$ \\
\hline 4.25 & 952 & 16,524 & 38,637 & Paratylenchus \\
\hline
\end{tabular}

\section{DISCUSSION}

T. semipenetrans was the most frequent and abundant plant-parasitic nematode in the orchards of Catalonia, as also happens in other citrus-growing regions of Spain $(1,25,26)$.

In this study, the main factors explaining the variability among orchards were organic matter, clay, $\mathrm{K}$, and $\mathrm{Mg}$ soil contents. Although none of the physicochemical properties of soil were correlated singly with nematode populations, the multiple regression explained a small amount of variability (16\%) in numbers of $\mathrm{J} 2+$ males in soil. Thus, nematode population densities in soil were negatively related to concentration of
This is the first study conducted in Spain that relates citrus nematode densities with potential yield losses. Gain threshold and economic threshold were calculated as tools for decision making to estimate the amount of yield gain and the density of nematodes that economically justify the use of control methods. The tolerance limit of cv. Clemenules on the citrange rootstocks is 287 females per gram of root. In all, $40 \%$ of the mandarin orchards surveyed in Catalonia ( 25 of 62 orchards) had population densities that exceeded the tolerance limit and potentially may suffer nematode damage if no other limiting factor were present. However, management should not be considered until the gain equals or exceeds the cost of the management options. The estimated economic threshold, considering the price of mandarins of 2003 and 2004, ranged from 330 to 710 females per gram of root, which indicates that approximately $22 \%$ of the cv. Clemenules orchards in Catalonia might find management profitable. Nevertheless, these threshold values should be taken cautiously because the data set is small (three orchards and 2 years) and because numerous factors $(7,9)$ affect the citrus nematode-plant interactions in a given region. Additionally, the price of mandarins is subjected to fluctuation; therefore, it is advisable to use an averaged price of the last several years to estimate economic threshold to reduce variability. The estimated economic threshold was similar to those at which nematicide treatments are recommended in California for samples taken in February to April (12), but higher than those recommended at South Africa (100 females per gram of root; 17).

Assessment of yield loss in mature citrus orchards depends on long-term cumulative stress (8); therefore, we propose density of females per gram of root as the best indicator to predict yield losses because this represents the success of the previous nematode inoculum in soil. Furthermore, densities of females per gram of root have been shown to be more consistent than juveniles in soil for comparing seasonality between years and orchards (35), evaluating the efficacy of nematicides (16), and indicating the damage potential to the tree $(5,12)$.

Although the number of females in roots is the best nematode stage to relate damage to the crop, the damaging effect on the yield will result from the damage the nematode already has caused at sampling (March) because the number of fruit has been determined (16). Subsequently, the effect of nematicides on citrus yield will be shown after the first- (23), second$(2,6,36)$, or third-year applications (14) The efficacy of nematicides has been estimated at $70 \%$ on average $(6,15,38)$. Citrus yield increase due to nematicide treatments has been reported between 15 and 30\% (8). Although more research will be necessary 
Table 4. Fluctuations of population densities of Tylenchulus semipenetrans in two clementine mandarin orchards cv. Clemenules (El Pla and Mariclaire orchards), and one cv. Hernandina (Martorella orchard) for two consecutive years

\begin{tabular}{llccc}
\hline & & \multicolumn{3}{c}{ Nematode population densities $^{\mathbf{z}}$} \\
\cline { 3 - 5 } Orchard, year & Season & Females & Eggs & Juveniles \\
\hline Martorella & & & \\
2003 & Spring & $656 \pm 391 \mathrm{a}^{*}$ & $12,296 \pm 5,664 \mathrm{a}^{*}$ & $8,327 \pm 2,303 \mathrm{a}^{*}$ \\
& Autumn & $297 \pm 125 \mathrm{~b}^{+}$ & $2,606 \pm 1,869 \mathrm{~b}$ & $6,934 \pm 3,567 \mathrm{a}^{+}$ \\
2004 & Spring & $206 \pm 92 \mathrm{a}$ & $5,704 \pm 2,418 \mathrm{a}$ & $5,666 \pm 2,051 \mathrm{a}$ \\
& Autumn & $150 \pm 229 \mathrm{~b}$ & $1,505 \pm 1,488 \mathrm{~b}$ & $4,027 \pm 3,526 \mathrm{a}$ \\
El Pla & & & & \\
2003 & Spring & $1,557 \pm 512 \mathrm{a}^{*}$ & $31,015 \pm 7,027 \mathrm{a}^{*}$ & $27,236 \pm 5,714 \mathrm{a}^{*}$ \\
& Autumn & $621 \pm 257 \mathrm{~b}^{+}$ & $6,610 \pm 4,406 \mathrm{~b}$ & $12,956 \pm 4,276 \mathrm{~b}^{+}$ \\
2004 & Spring & $421 \pm 146 \mathrm{a}$ & $7,475 \pm 2,002 \mathrm{a}$ & $8,064 \pm 2,810 \mathrm{~b}$ \\
\multirow{2}{*}{ Mariclaire } & Autumn & $296 \pm 184 \mathrm{a}$ & $4,352 \pm 2,942 \mathrm{~b}$ & $20,265 \pm 4,195 \mathrm{a}$ \\
2003 & & & & \\
2004 & Spring & $534 \pm 278$ & na & $29,947 \pm 16,314^{*}$ \\
\hline
\end{tabular}

${ }^{\mathrm{z}}$ Population is measured per gram of root for females and eggs and per $250 \mathrm{~cm}^{3}$ of soil for juveniles. Data were transformed to $\log _{10}(x+1)$ before analysis. Values are back-transformed mean \pm standard deviation of 10 replications. Data for each orchard and year followed by the same letter are not significantly different $(P<0.05)$ according to Student's $t$ tests. Data for each orchard followed by * or ${ }^{+}$ are significantly different $(P<0.05)$ in spring or autumn between years, respectively, according to Student's $t$ tests; na $=$ data not available.

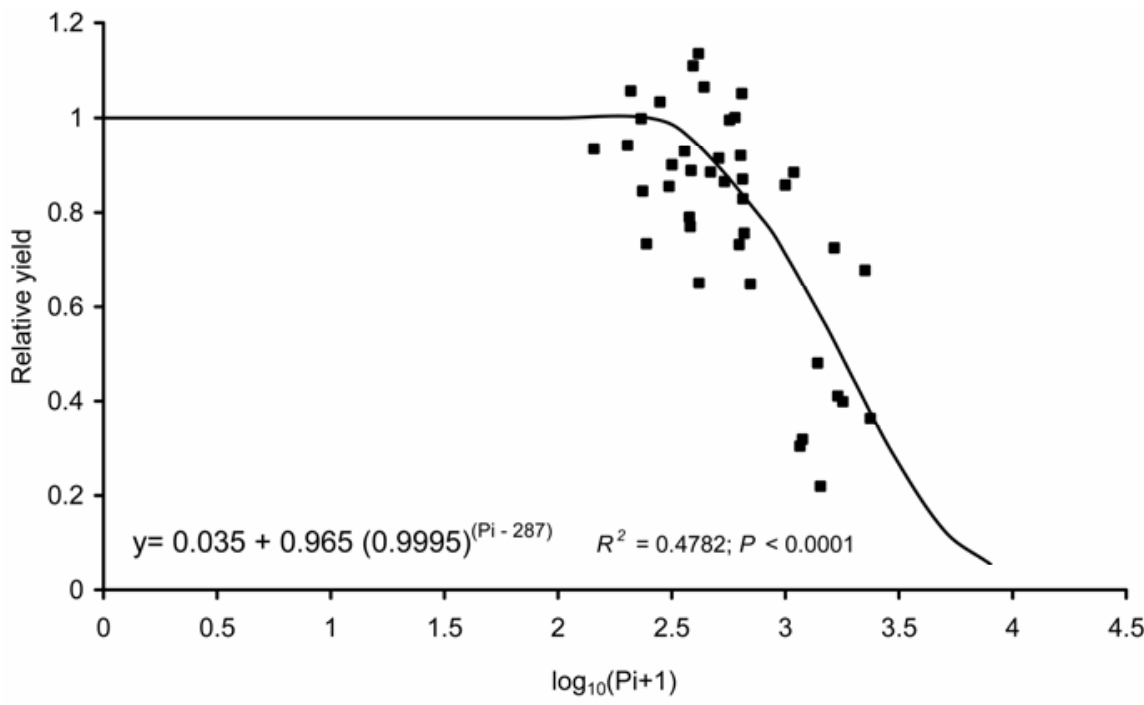

Fig. 2. Seinhorst damage function model: relationship between relative yield of clementine mandarin cv. Clemenules and population densities of females of Tylenchulus semipenetrans per gram of root in spring.

to substantiate economic threshold values, they can be taken as a benchmark and will be helpful to provide guidance to the growers.

\section{ACKNOWLEDGMENTS}

We thank the Instituto Nacional de Investigación Agraria y Alimentaria of Spain for economic support through grants no. RTA02-068 and RTA 05-86, and the European Research Program of Dupont for economic support; M. and C. Fabregat and B. Barberá for facilitating the yield trials; and L. W. Duncan and N. Greco for comments on an earlier version of the manuscript.

\section{LITERATURE CITED}

1. Bello, A., Navas, A., and Belart, C. 1986. Nematodes of citrus groves in the Spanish Levante. Ecological study focused to their control. Pages 217-226 in: Integrated Pest Control in Citrus groves. R. Cavalloro and E. Di Martino, eds. A. A. Balkema Publishing Co., Rotterdam, The Netherlands.

2. Childers, C. C., Duncan, L. W., Wheaton, T.
A., and Timmer, L. W. 1987. Arthropod and nematode control with aldicarb on Florida citrus. J. Econ. Entomol. 80:1064-1071.

3. Cohn, E. 1972. Nematode diseases of citrus. Pages 215-244 in: Economic Nematology. J. M. Webster, ed. Academic Press, London.

4. Davide, R. G. 1971. Survey of the distribution of different plant parasitic nematodes associated with the citrus decline in the Philippines. A report of NSDB project no. 2203, University of Philippines, College of Agriculture, Laguna.

5. Duncan, L. W. 1986. The spatial distribution of citrus feeder roots and of the citrus nematode, Tylenchulus semipenetrans. Rev. Nematol. 9:233-240.

6. Duncan, L. W. 1989. Effect of fenamiphos placement on Tylenchulus semipenetrans and yield in a Florida citrus orchard. J. Nematol. 21:703-706.

7. Duncan, L. W. 1999. Nematode diseases of citrus. Pages 136-148 in: Citrus Health Management. L. W. Timmer and L. W. Duncan, eds. American Phytopathological Society Press, St. Paul, MN.

8. Duncan, L. W. 2005. Nematode parasites of citrus. Pages 437-466 in: Plant Parasitic nematodes in Subtropical and Tropical Agriculture. M. Luc, R. A. Sikora, and J. Bridge, eds. Commonwealth Agricultural Bureau International, Wallingford, UK.

9. Duncan, L. W., and Cohn, E. 1990. Nematode parasites of citrus. Pages 321-346 in: Plant Parasitic Nematodes in Subtropical and Tropical Agriculture. M. Luc, R. A. Sikora, and J. Bridge, eds. Commonwealth Agricultural Bureau International, Wallingford, UK.

10. Duncan, L. W, Mashela, P., Ferguson, J., Graham, J., Abou-Setta, M. M., and El-Morshedy, M. M. 1995. Estimating crop loss in orchards with patches of mature citrus trees infected by Tylenchulus semipenetrans. Nematropica 25:43-51.

11. Ferris, H. 1978. Nematode economic thresholds: derivation, requirements, and theoretical considerations. J. Nematol. 10:341-350.

12. Garabedian, S., Van Gundy, S., Mankau, R., and Radewald, J. D. 1984. Nematodes. Pages 129-131 in: Integrated Pest Management for Citrus. Division of Agriculture and Natural Resources Publications, University of California, Berkeley.

13. Gené, J., Verdejo-Lucas, S., Stchigel, A.M., Sorribas, F. J., and Guarro, J. 2005. Microbial antagonists associated with Tylenchulus semipenetrans in citrus orchard of Catalonia Spain. Biocontrol Sci. Technol. 15:721-731.

14. Greco, N., Basile, M., D'Addabbo, T., and Brandosino, A. 1993. Influence of aldicarb and fenamiphos on Tylenchulus semipenetrans population densities and orange yield. J. Nematol. 25:768-772.

15. Hamid, G. A., Van Gundy, S. D., and Lovatt, C. J. 1985. Citrus nematode alters carbohydrate partitioning in the "Washington" Navel orange. J. Am. Soc. Hortic. Sci. 110:642-646.

16. Hamid, G. A., Van Gundy, S. D., and Lovatt, C. J. 1988. Phenologies of the citrus nematode and citrus roots treated with oxamyl. Pages 993-1004 in: Proc. 6th Int. Citrus. Congress. Tel Aviv, Israel. R. Goren and K. Mendel, eds. Balaban Publishers, Philadelphia and Rehovoth, Israel.

17. Le Roux, H. F., Pretorius, M. C., and Huisman, L. 2000. Citrus nematode IPM in Southern Africa. Proc. Int. Soc. Citricult. Vol. 2:823-827.

18. Mangat, B. P. S., and Sharma, N. K. 1981 Influence of host nutrition on multiplication and development of citrus nematode. Indian Phytopathol. 34:90-91.

19. Martin, J. P., and Van Gundy, S. D. 1963 Influence of soil phosphorous level on the growth of sweet orange seedlings and the activity of the citrus nematode (Tylenchulus semipenetrans). Soil Sci. 96: 128-135.

20. Martínez-Fuentes, A., Mesejo, C., Juan, M. Almela, V., and Agustí, M. 2003. Acción del paclobutrazol sobre la floración de los cítricos y su relación con el metabolismo de los azúcares. X Congreso Nacional de Ciéncias Hortícolas. Pontevedra. Acta Hortic. 39:303304.

21. Martínez-Fuentes, A., Mesejo, C., Juan, M. Almela, V., and Agustí, M. 2004. Restrictions on the exogenous control of flowering in citrus. Acta Hortic. 632:91-98.

22. Mashela, P., Duncan, L. W., Graham, J. H., and McSorley, R. 1992. Leaching soluble salts increases population densities of Tylenchulus semipenetrans. J. Nematol. 24:103-108.

23. McClure, M. A., and Schmitt, M. E. 1996. Control of citrus nematode, Tylenchulus semipenetrans, with cadusafos. J. Nematol. 28:624-628.

24. McSorley, R., Parrado, J. L., and Dankers, W. H. 1984. A quantitative comparison of some methods for the extraction of nematodes from roots. Nematropica 14:72-84.

25. Navas, A., Nombela, G., and Bello, A. 1992. Caracterización de la modalidad de dis- 
tribución de Tylenchulus semipenetrans en el levante español. Nematropica 22:205-216.

26. Nombela, G., Lara, M. P., and Navas, A. 1990. Umbrales de daño en Nematología. Caracterización epidemiológica de Tylenchulus semipenetrans en los cítricos de Guadalquivir. Levante Agrícola 297:46-49

27. O'Bannon, J. H. 1968. The influence of an organic soil amendment on infectivity and reproduction of Tylenchulus semipenetrans on two citrus rootstocks. Phytopathology 58:597601.

28. Oka, Y., Tkachi, N., Shuker, S., Rosenberg, R., Suriano, S., and Fine, P. 2006. Laboratory studies on the enhancement of nematicidal activity of ammonia-releasing fertilisers by alkaline amendments. Nematology 8:335-346.

29. Philis, J. 1989. Yield loss assessment caused by the citrus nematode Tylenchulus semipenetrans on Valencia oranges in $\mathrm{Cy}$ - prus. Nematol. Mediterr. 17:5-6.

30. Pedigo, L. 1989. Entomology and Pest Management. MacMillan Publishing Company, New York.

31. Pettigrew, W. T., Meredith, W. R., and Young, L. D. 2005. Potassium fertilization effects on cotton lint yield, yield components, and reniform nematode populations. Agron. J. 97:1245-1251.

32. Rodriguez-Kábana, R. 1986. Organic and inorganic nitrogen amendments to soil as nematode suppressants. J. Nematol. 18:129135 .

33. Seinhorst, J. W. 1965. The relationship between nematode density and damage to plants. Nematologica 11:137-154.

34. Sharma, G. C., Thakur, B. S., and Kashyap, A. S. 2005. Impact of NPK on the nematode populations and yield of plum (Prunus salicina). Acta Hortic. 696:433-436.
35. Sorribas, F. J., Verdejo-Lucas, S., Forner, J. B Alcaide, A., Pons, J., and Ornat, C. 2000. Seasonality of Tylenchulus semipenetrans Cobb and Pasteuria sp. in citrus orchards in Spain. J. Nematol. 32:622-632.

36. Tarjan, A. C., and O'Bannon, J. H. 1974. Postplant fumigation with DBCP for citrus nematode control in Florida. J. Nematol. 1:41-48.

37. Timmer, L. W., and Davis, R. D. 1982. Estimate of yield loss from the citrus nematode in Texas grapefruit. J. Nematol. 14:582-585.

38. Timmer, L. W, and French, J. V. 1979. Control of Tylenchulus semipenetrans on citrus with aldicarb, oxamyl and DBCP. J. Nematol. 11:387-394.

39. Van Gundy, S. D., Martin, J. P., and Tsao, P. H. 1964. Some soil factors influencing reproducion of the citrus nematode and growth reduction of sweet orange seedlings. Phytopathology 54:294-299. 